\title{
EVALUATION OF ENLIGHTENMENT PROGRAMMES ON REDUCTION OF MOTHER-CHILD MORTALITY RATES IN NIGERIAN RURAL COMMUNITIES: MONIYA, OYO STATE AS A CASE STUDY
}

\author{
Oyindamola A Taiwo, \\ Phd, Mass Communication Dept, \\ Amhadu Bello University, Zaria, Kaduna, Nigeria; \\ Ademola A Taiwo, \\ Phd, Jpl Dept. School of Law \& Security Studies, \\ Babcock University, Ilisan Remo, Ogun State, Nigeria
}

\begin{abstract}
In Nigeria today, there is for continuum enlightenment policy on ways and means of combating mortality rate in the rural areas. Hence, the main focus of this study is to evaluate enlightenment programmes of mother-child mortality rates particularly in the rural communities. The study further evaluated the impact of enlightenment programmes in reducing mother child mortality rate in Nigerian rural settings. In doing this, various literature and theories were used to support the study. A focus group interview was conducted among the people living in Moniya community for primary data while secondary data were gathered from article, scholarly relevant books and journals published by authors in this area of study and same from the internet/ electronics media. The primary data were analyzed through the simple percentage method. It was gathered that respondents are aware of mother-child death and suggested some causes and solution to the problem. Considering this finding, it was recommended that government at all levels, even governmental institutions, NGOs, private individuals and philanthropists should help; in making life better for mother and child.
\end{abstract}

KEY WORDS: Enlightenment, Programmes, Mortality rate, Rural Communities, Evaluation.

I. INTRODUCTION
Mother and child mortality has been at the hub of health discourse since time immemorial. Governments, health professions and policy makers have reserved an exclusive interest in reducing the prevalence of childhood deaths globally. However, in a report by Oyewale Mayowa \&Adeniyi Francis (2017), this has not only extended into the international scene, it has led to the development of sound interventions to reducing child mortality among children under the age of five between 1990 and 2015 and between 2015 and 2030 as tagged in the United Nations Millennium Development Goals (MSDGS) and Sustainable Development Goals (SDGS) respectively.

Maternal Mortality unacceptably high amount 830 women die from pregnancy or childbirth-related complications around the world every day. It was estimated that in 2015 , roughly 303,000 women died during and following pregnancy and childbirth. Almost all of their deaths occurred in cow-resource settings and most could have been presented (WHO, 2018).

In sub-Saharan Africa a number of countries valued their levels of their maternal mortality since 1990. Between 1990 and 2015 the global maternal mortality ration (the number of maternal deaths per 100,000 live births) declined by only $2.3 \%$ per year. Between 1990 and 2015 the maternal mortality ration in developing countries in 2015 is 239 per 100,000 live births this is still high compared to that of developed countries which is 12 per 100,000 live births. 
Nigeria falls in this category of sub-Saharan Africa and developing countries. Nigeria in the past far yeas has experienced worsening of child mortality. This was between 1990 and 2003 according to WHO but there was a decline in neonatal rate in Nigeria by 20.4\% from 49 deaths per 1000 live births in 1990 to 39 in 2011,37 in 2013 and 34 deaths per 1000 live births in 2015 (O.M. Morakinyo \& A.F. Fagbamigbe, 2017) global Nigeria ranks second to zonal with the high heart number of neonatal deaths (UNICEF; 2015) the mass media is an instrument for correcting the ills in the society is powerful enough to make sure correction in this area. First, communication for development is crucial for my development to be achieved in area of the society.

\section{DEVELOPMENT COMMUNICATION}

Refers to thereof communication to facilitate social development Nora C. Quebral(1972 - 1973). Recently, there has been a lot of emphasis on the childcare using both electronic and print media to reach out to the set of people concerned through different enlightenment development oriented programmes articles, the question is; do these programmes contain the solutions to these problems or has it affected the rate of mortality both maternal and infant.

Okunna (2002) as cited in Oyero Olusola (2003) noted that development communication has to do with mobilization of a people to have a positive change in their lively conditions. These people are provided with adequate knowledge and information so that they are persuaded through sound reasoning, to change in a predetermined direction to reduce to a significant percentage, with adequate knowledge and information of the causes and preventive methods of maternal and infant mortality.

\section{Causes of Maternal Mortality}

Women die as a result of complications during and following pregnancy and child birth. Most of these complications develop during pregnancy and most are preventable (WHO, 2018). The causes ranges from severe bleeding, infections, high blood pressure, unsafe abortion to malnutrition, ignorance or lack of information, poverty, cultural factors and so on.

\section{Ignorance and Illiteracy}

As it is said 'ignorance is a disease', when there is lack of knowledge/education or unawareness about something or an occurrence, it is going to cause one the price of not knowing, from a report gathered by Muhammad Abubakar (2008) in all Africa Electronic
Magazine, he stated the permanent secretary in Bauchi Sate Ministry of Heath Dr. Muhammad Ali Hussaini, has identified lack of sufficient knowledge by some Muslim clerics in Northern Nigeria as being responsible for the high level of maternal mortality in the area. The permanent secretary said because of their limited knowledge on some aspects of Islamic teachings, the religion leaders tend to preach against women going to hospital for anti-natal checkups as well as other consultations that would reduce maternal mortality. From report, it is obvious that the role of knowledgeable individuals are very important in reducing maternal mortality the 1999 NDHS (Naturals Demographic and Health Survey) reveals that lowers educational levels among females was related to higher infants and under 5 mortality (policy,2002).

\section{Impact of Mass Media in Development and Health Communication}

The channels of mass media especially the radio which is largely indigenous, affordable and accessible in the nook and crannies of every community has been used to pass across much information to its listens. Many people needlessly die every day due to lack of access to health information which would have allowed them to make appropriate disease. Therefore, access to reliable health information is a cornerstone of improved and sustainable outcomes (Collins O.F., Masford B, Albert N, 2016).

Mass media is one of the popular and cost effective public health promotion tools globally. It is the main source of health information many parts of the world. In Nigeria for example, man media is on major source of information about malaria, women's health, HIV/AIDS, family planning and so on (E. W. Nwagwu \& M. Ajama (2011) also in Tanzania, Malawi and other African Countries. The achievements of mass media in relations to this topic are immerse but still, more needs to be done.

The mass media has its limitations especially the Radio, Oyebode (2003) posited that Radio is not an omnipotent medium and that certain developments handle have proved very difficult for radio to across. Research has consistently suggested that radio is not very effective when it come to changing old habits and causing people to adopt new practices especially when such practices contradict some firmly held translations.

The radio does not reach every one with the development message; Lazarsfield Paul cited by 
Bogue Donald(1979) in Oyebode (2003) discovered that it is people who are formally educated again have the productivity to the radio for education while illiterates patronize radio for entertainment. In other words, when people tune in to radio, they are looking for entertainment or background noise

Various Enlightenment Programmes have been aimed in regards to health, women and children care. The study is taking at look at its impact on the development of rural community in Moniya, Oyo Sate. This will also involve examining the participation level of the people.

\section{THEORETICAL FRAMEWORK}

The study hangs on the Development Media theory as summed up by McQuail (1987:121) in Folarin (1998) "Media must accept and carry out positive development takes in line with nationally established policy". This establishes the fact that the media in meant to introduce, disease and improve development oriented programmes in line with their country/community needs.

Also to check the effectiveness impact of the message, the man media is paring to its audience the Harold Laswell's communication model (1948) requires answers to the following questions who, says what in what channel, to whom and with what effect. The model identifies the source, the message the medium, the receiver and the effectiveness, impact of the message on the receiver: which is very central to this study.

\section{METHODOLOGY}

In order to generate qualitative data, a focus group interview was adopted for primary data gathering. The focused group discussion was held with pregnant and nursing mothers from Moniya, Akinyele local government of Oyo State in their primary health center. The mothers' age groups were between $20-25$ and 26 - 30 years of age. The discussion was led and facilitated by the researcher and coordinated by the Nurse in charge of pregnant and nursing mothers.

\section{Presentation of Focus Group Interview Result}

\section{(a)Knowledge and Awareness of Maternal Mortality}

From the discussions hold by the two groups, it was discovered that they are aware that people/women die during pregnancy and child birth. Some of the discussion share experiences of neighbors or friend who have been at times of mortality. This shows that they are in the known and have seen example.

\section{(b) Knowledge and Awareness of Enlightenment programme.}

In the discussion it was realized that two major programmes are been aired on their community radio basically to discussions women and children's health. The programmes are "Obirin Ndabira" and " Akinkanju Obirin? Which are also in indigenous language to ensure understanding? But still from the discussions, some of the enjoy the entertainment part of the programme rather than the educative parts it shows that they are yet to have a full knowledge of the maternal mortality rate. This might be as a result of time limitation in their just 30 minutes programmes aired once a week. And all the segments cannot be maximized enough to ensure comprehension and understanding of the subject matters treated on the shows.

\section{(c) Motivation of Audience to take Action:}

The pregnant women mentioned that they have received free delivery kits from some NGOs and that is due to enlightenment programs asserted that there have been in increase in the number of people that attends the ante natal care since awareness began. They shared their personal experiences and how the programme has made them to take one positive action or the other as regards their health. They emphasized on community participation which is key in making sure the message achieves its goals and impact. The effect of the message through the radio can be measured by the level of action taken by all the stakeholders ranging from government to NGOs to the community itself.

(d) Impact on the Rate of Maternal Mortality in the community:

The nurses in charge compared the statistics of 2000 to 2010 and 2011 to 2018 , they confirmed that there have been about $20 \%$ reduction in the mortality rate in the community but there is still room for more improvement. They suggested adoption of area meeting, time to time orientation programmes for mothers and intending mothers to boost their knowledge about the issues surrounding Maternal/Child Mortality especially preventive measures. This also agrees with Freire (1983) cited in Anaeto, Onabajo and Asifeso (2008) which suggests a reciprocal collaborations of all stakeholders involved to contributed and participate in the task of transforming society through information showing, knowledge, trust, commitment and a right attitude in development planning and implementation. 


\section{International Journal of Engineering Applied Sciences and Technology, 2019 Vol. 4, Issue 3, ISSN No. 2455-2143, Pages 515-518 \\ Published Online July 2019 in IJEAST (http://www.ijeast.com)}

\section{CONCLUSION}

It can therefore be concluded that enlightenment programmes helps in reducing mother-child mortality rate in the community and Nigeria at large. In the words of Abdul-Aziz, Haruna, Ismail F.O \& Baba.D (2015:29) "It is believed that any programme that is meant to change community perception require the direct involvement and participation of all stakeholders in the programme. It is believed that failure to carry along all stakeholders is a prerequisite to failure of the programme."Also employing the medium of radio and coupling it with provisions of other amenities, the help of government, private persons and NGOs, the living conditions of many people will be better.

\section{RECOMMENDATIONS}

The study therefore recommends that:

$>$ Government should create more health care centers and employ more health workers who are indigenous and skilled in the area of women and children.

$>$ Involvement of all stakeholders in ensuring accessible information and health facilities.

$>$ Education of the Girl-child who are the future mothers and care givers and equally adopt a catch them young policy..

$>$ The policies of UNICEF, WHO and USAID should be closely supervised to ensure maximum implementation by the state relevant authorites.

$>$ Radio and other media should be empowered to do more as regards women/child health care information dissemination.

\section{REFERENCES}

1. Abdul Aziz, Haruna, Ismail F.O, \& Baba, $\mathrm{D}(2015)$ Knowledge of polio virus among nursing mothers in Anguwan Giwa LGA of Kaduna State. Zaria; Zaria Journal of Mass Communication. Vol 3. No 2. Page $23-30$.

2. Anaeto, Onabanjo and Osifeso (2008). Model, and theories of communication USA: African renaissance books incorporated .

3. Collins O. F. Zamawe, Masford Banda Albert N. Dube (2016). The impact of a community driven mass media campaign on the Utilization of maternal health care services in rural media. BMC pregnancy and childbirth BMC series.
4. Denis, McQuails (2008). McQuial's Mass Communication Theory, $5^{\text {th }}$ Edition. London, Sage Publication Limited.

5. Folarin Babatunde (1998) Theories of mass communication: An introduction. Ibadan, Stirling Holden Publishers.

6. Morakinyo O.M. \& Fagbamigbe A.F (2017) Neonatal, infant and under five mortalities in Nigeria; An examination of trends and drivers (2003 - 2013). PLoS ONE12 (8); 0182990 Retrieved Tuesday, $3^{\text {rd }} 2019$.

7. Muhammad Abdulbakar (2008). Nigeria: Ignorance, cause of Maternal Mortality Abuja Daily Trust as sited in All Africa.

8. Nwagwu W.E, Ajama M. (2011) Women's Health Information Needs and Information sources: a study of a rural oil palm business community in South-Western Nigeria. Page 270-281 Google scholar. http://hdl.handle.net/123456789/12844.

ISSN-0975-2404 Retrieved Tuesday, $3^{\text {rd }}$ 2019.

9. Oyebode F. (2003), Indigenous language radio for development purposes. Ibadan, Kraft books limited

10. Oyero, O. S. (2003), Development Journalism and Broadcasting (Development Communication). Course Module, Lagos: National Open University of Nigeria. 195 Pages.

11. Oyewale Mayowa \&Adeniyi Francis (2017). Neonatal, infant and under-five mortalities in Nigeria: An examination of trends and drivers.

https://doi.org/10.1371//journal.pone.018299

0. Retrieved Tuesday 3rd July, 2019.

12. Quebral, Nora C. (1972-1973) "what do we mean by Development Communication?" international development review 15(2): 2528.

https://onlinelibrary.wiley.com/journal/1099 1328 Retrieved Tuesday, $3^{\text {rd }} 2019$.

13. UNICEF/WHO/UN levels and trends in child mortality. UNICEF. New York, USA; 2015.

www.un.org/en/development/desa/polpulati on/mortality/child-mortality.2015.asp

Retrieved Tuesday, $3^{\text {rd }} 2019$.

14. WHO (2018) Maternal Mortality. www.who.int/news-room/factssheets/details/maternal-mortality Retrieved $\begin{array}{lll}\text { Tuesday, } & 3^{\text {rd }} & 2019 .\end{array}$ 